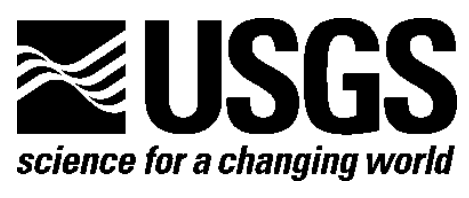

\title{
Cobalt-Styles of Deposits and the Search for Primary Deposits
}

By Murray W. Hitzman, Arthur A. Bookstrom, John F. Slack, and Michael L. Zientek

Open-File Report 2017-1155

U.S. Department of the Interior

U.S. Geological Survey 


\title{
U.S. Department of the Interior \\ RYAN K. ZINKE, Secretary
}

\section{U.S. Geological Survey \\ William H. Werkheiser, Deputy Director exercising the authority of the Director}

\author{
U.S. Geological Survey, Reston, Virginia: 2017
}

\begin{abstract}
For more information on the USGS—the Federal source for science about the Earth, its natural and living resources, natural hazards, and the environment-visit https://www.usgs.gov/ or call 1-888-ASK-USGS (1-888-275-8747).
\end{abstract}

For an overview of USGS information products, including maps, imagery, and publications, visit https://store.usgs.gov/.

Any use of trade, firm, or product names is for descriptive purposes only and does not imply endorsement by the U.S. Government.

Although this information product, for the most part, is in the public domain, it also may contain copyrighted materials as noted in the text. Permission to reproduce copyrighted items must be secured from the copyright owner.

Suggested citation:

Hitzman, M.W., Bookstrom, A.A., Slack, J.F., and Zientek, M.L., 2017, Cobalt-Styles of deposits and the search for primary deposits: U.S. Geological Survey Open-File Report 2017-1155, 47 p., https://doi.org/10.3133/ofr20171155.

ISSN 2331-1258 (online) 


\section{Contents}

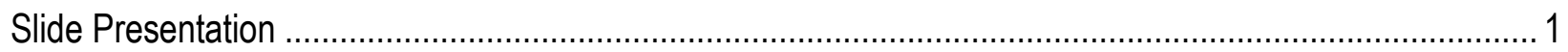



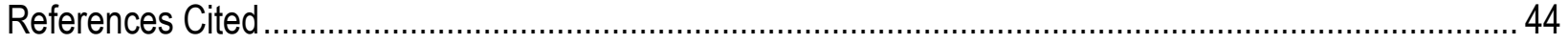




\section{Conversion Factors}

\begin{tabular}{|c|c|c|}
\hline Multiply & By & To obtain \\
\hline \multicolumn{3}{|c|}{ Length } \\
\hline centimeter $(\mathrm{cm})$ & 0.3937 & inch (in.) \\
\hline millimeter (mm) & 0.03937 & inch (in.) \\
\hline meter (m) & 3.281 & foot (ft) \\
\hline kilometer (km) & 0.6214 & mile (mi) \\
\hline meter $(\mathrm{m})$ & 1.094 & yard (yd) \\
\hline \multicolumn{3}{|c|}{ Mass } \\
\hline gram $(\mathrm{g})$ & 0.03527 & ounce, avoirdupois (oz) \\
\hline metric ton $(\mathrm{t})$ & 1.102 & ton, short $[2,000 \mathrm{lb}]$ \\
\hline metric ton $(\mathrm{t})$ & 0.9842 & ton, long $[2,240 \mathrm{lb}]$ \\
\hline
\end{tabular}

Temperature in degrees Celsius $\left({ }^{\circ} \mathrm{C}\right)$ may be converted to degrees Fahrenheit $\left({ }^{\circ} \mathrm{F}\right)$ as ${ }^{\circ} \mathrm{F}=\left(1.8 \times{ }^{\circ} \mathrm{C}\right)+32$. 


\section{Abbreviations}

$\begin{array}{ll}\mathrm{Ag} & \text { silver } \\ \mathrm{As} & \text { arsenic } \\ \mathrm{Au} & \text { gold } \\ \mathrm{Bi} & \text { bismuth } \\ \mathrm{bn} & \text { bornite } \\ \mathrm{bt} & \text { biotite } \\ \mathrm{C} & \text { carbon } \\ \mathrm{CACB} & \text { Central African Copperbelt } \\ \mathrm{CCB} & \text { Congo Copperbelt } \\ \mathrm{Cl} & \text { chlorine } \\ \mathrm{Co} & \text { cobalt } \\ \mathrm{cob} & \text { cobaltite } \\ \mathrm{Congo} \text { (Kinshasa) } & \text { Democratic Republic of the Congo } \\ \mathrm{CP} & \text { chalcopyrite (appears in this form on page 22 only; elsewhere, } \\ \mathrm{cpy} & \text { cpy) chalcopyrite } \\ \mathrm{cr} & \text { carrollite } \\ \mathrm{Cr} & \text { chromite } \\ \mathrm{Cu} & \text { copper } \\ \mathrm{EEZ} & \text { exclusive economic zone } \\ \mathrm{Fe} & \text { iron } \\ \mathrm{hm} & \text { hematite } \\ \mathrm{IOCG} & \text { iron oxide-copper-gold } \\ \mathrm{Ma} & \text { mega-annum } \\ \mathrm{Mg} & \text { magnesium } \\ \mathrm{mgt} & \text { magnetite } \\ \mathrm{Mn} & \text { manganese } \\ \mathrm{MnS} & \text { alabandite } \\ \mathrm{MVT} & \text { Mississippi Valley-type } \\ \mathrm{Ni} & \text { nickel } \\ \mathrm{Os} & \text { osmium } \\ \mathrm{Pb} & \text { lead } \\ \mathrm{PGE} & \text { platinum-group element } \\ \mathrm{ppm} & \text { part per million } \\ \mathrm{py} & \text { pyrite } \\ \mathrm{q} & \text { quartz } \\ \mathrm{Re} & \text { rhenium } \\ \mathrm{REE} & \text { rare-earth element } \\ \mathrm{saf} & \text { safflorite } \\ \text { to } & \text { toumaline } \\ \mathrm{U} & \text { uranium } \\ \mathrm{VMS} & \text { volcanogenic massive sulfide } \\ \mathrm{ZCB} & \text { Zambian Copperbelt } \\ \mathrm{Zn} & \text { zinc } \\ & \end{array}$





\section{ॠUSGS

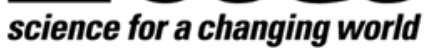

\section{Cobalt - Styles of Deposits and the Search for Primary}

Deposits

Murray W. Hitzman, Arthur A. Bookstrom, John F. Slack, and Michael L. Zientek 


\section{Abstract}

Cobalt (Co) is a potentially critical mineral. The vast majority of cobalt is a byproduct of copper and (or) nickel production. Cobalt is increasingly used in magnets and rechargeable batteries. More than 50 percent of primary cobalt production is from the Central African Copperbelt. The Central African Copperbelt is the only sedimentary rock-hosted stratiform copper district that contains significant cobalt. Its presence may indicate significant mafic-ultramafic rocks in the local basement. The balance of primary cobalt production is from magmatic nickel-copper and nickel laterite deposits. Cobalt is present in several carbonatehosted lead-zinc and copper districts. It is also variably present in Besshi-type volcanogenic massive sulfide and siliciclastic sedimentary rock-hosted deposits in back arc and rift environments associated with mafic-ultramafic rocks. Metasedimentary cobalt-copper-gold deposits (such as Blackbird, Idaho), iron oxide-copper-gold deposits, and the five-element vein deposits (such as Cobalt, Ontario) contain different amounts of cobalt. None of these deposit types show direct links to mafic-ultramafic rocks; the deposits may result from crustal-scale hydrothermal systems capable of leaching and transporting cobalt from great depths. Hydrothermal deposits associated with ultramafic rocks, typified by the Bou Azzer district of Morocco, represent another type of primary cobalt deposit.

In the United States, exploration for cobalt deposits may focus on magmatic nickel-copper deposits in the Archean and Proterozoic rocks of the Midwest and the east coast (Pennsylvania) and younger mafic rocks in southeastern and southern Alaska; also, possibly basement rocks in southeastern Missouri. Other potential exploration targets include-

- The Belt-Purcell basin of British Columbia (Canada), Idaho, Montana, and Washington for different styles of sedimentary rock-hosted cobalt deposits;

- $\quad$ Besshi-type VMS deposits, such as the Greens Creek (Alaska) deposit and the Ducktown (Tennessee) waste and tailings; and

- Known five-element vein districts in Arizona and New Mexico, as well as in the Yukon-Tanana terrane of Alaska; and hydrothermal deposits associated with ultramafic rocks along the west coast, in Alaska, and in the Appalachian Mountains.

\section{ఇUSGS}




\section{Cobalt-Properties and Uses}

- Cobalt is a silvery gray metal.

- Key properties:

o Ferromagnetism (even at high temperature).

o Hardness and wear-resistance when alloyed with other metals.

o Low thermal and electrical conductivity.

o High melting point.

o Intense blue color when combined with silica.

- Uses:

o Cathodes in rechargeable batteries-lithium-ion, Ni-Cd, Ni-metal-hydride.

o Superalloys for turbine engines in jets and terrestrial energy generation.

o Magnet applications-marine propulsion, missile guidance, sensors, and radar.

o Cemented carbides-cutting tools and wear-resistant components (for use in construction, oil and gas extraction, mining, metalworking).

\section{ॠUSGS}




\section{Cobalt-Critical Mineral?}

\section{"Critical" means you need it; "strategic" means you don't have it}

- Cobalt is not currently considered a "critical" mineral, but it has the potential to become one in the future (McCullough and Nassar, 2017).

- Most cobalt is produced as a byproduct (of copper or nickel mining), which limits the flexibility of producers to respond to changes in market demand and results in periods of oversupply or shortage.

- More than $50 \%$ of primary cobalt production is from Congo (Kinshasa)-a country that ranks high on the 'risk of doing business' index because of its political instability; another $16 \%$ of primary cobalt production is from Russia, Cuba, and China combined (U.S. Geological Survey, 2017, p. 52-53).

- The United States imports $75 \%$ to $80 \%$ of its supply. Most of the remaining $20 \%$ to $25 \%$ is from recycled scrap. The leading source of refined cobalt is China (U.S. Geological Survey, 2017, p. 52-53).

\section{刃USGS}




\section{Cobalt-Current Sources of Primary Production}

- The majority of the world's cobalt currently comes from Congo (Kinshasa).

- A number of other countries each contribute less than $10 \%$ to the total.

- In all cases except the Bou Azzer district (Morocco), cobalt is produced as a byproduct of other metals $(\mathrm{Cu}, \mathrm{Ni})$.

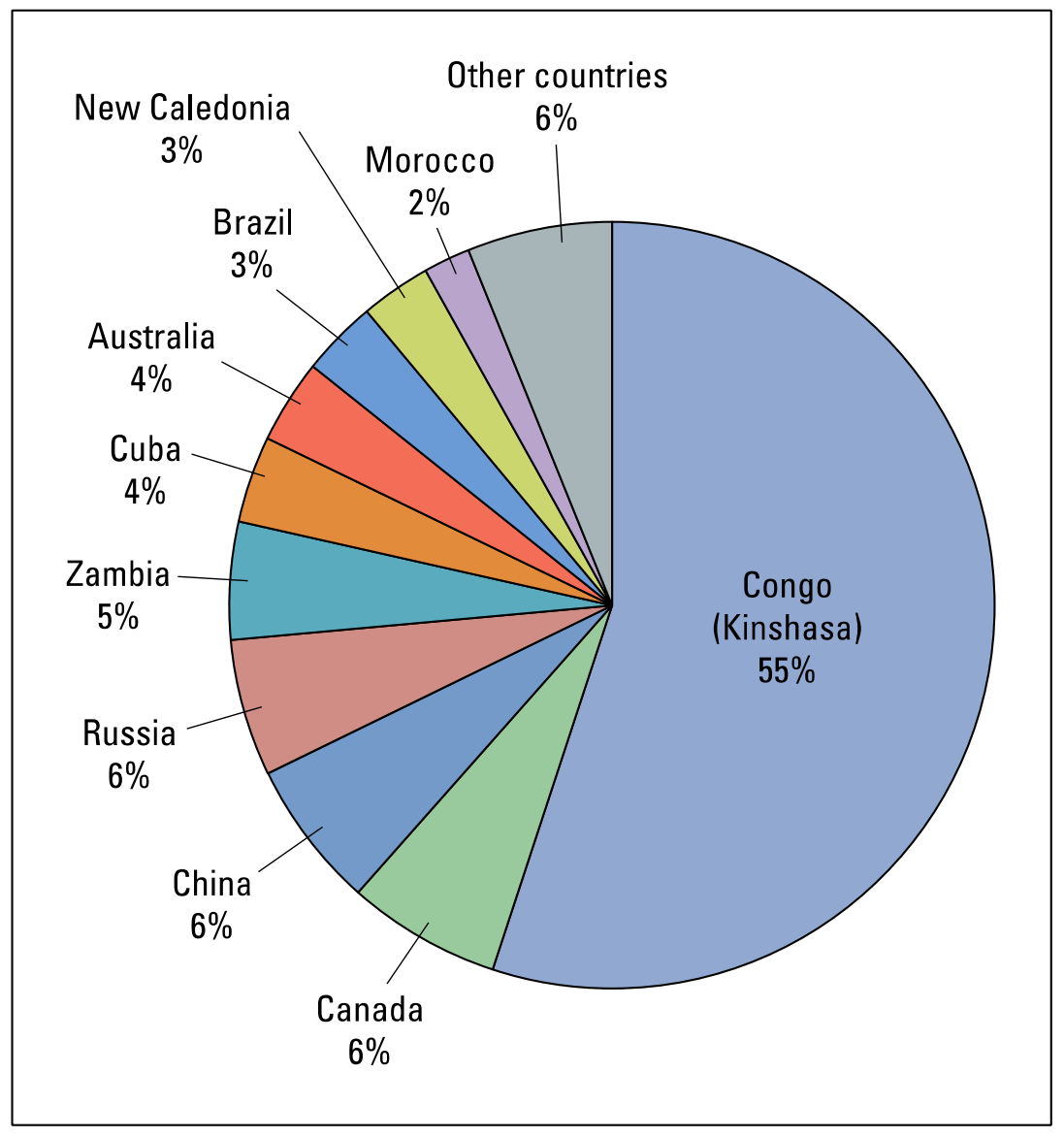

From Slack and others, in press. 


\section{Cobalt-Geochemistry}

- The ionic radii of $\mathrm{Co}^{2+}$ and $\mathrm{Co}^{3+}$ are similar to the ionic radii of $\mathrm{Mg}^{2+}, \mathrm{Mn}^{4+}, \mathrm{Fe}^{2+}, \mathrm{Fe}^{3+}$, and $\mathrm{Ni}^{2+}$.

- Cobalt can substitute for any of these elements in many minerals.

- The highest average cobalt content occurs in ultramafic rocks (dunite, serpentinite; $110 \mathrm{ppm}$ ) > mafic igneous rocks (basalt; $47 \mathrm{ppm}$ ) > shales (19 ppm) > granite ( $3 \mathrm{ppm})$. 


\section{Cobalt-Primary (Hypogene) Mineralogy}

- Sulfides:

- Carrollite $\mathrm{Cu}(\mathrm{Co}, \mathrm{Ni})_{2} \mathrm{~S}_{4}$

- Linnaeite $\mathrm{Co}_{3} \mathrm{~S}_{4}$

- Pentlandite $(\mathrm{Fe}, \mathrm{Ni}, \mathrm{Co})_{9} \mathrm{~S}_{8}$

o Siegenite $(\mathrm{Co}, \mathrm{Ni})_{3} \mathrm{~S}_{4}$

- Cobaltiferous iron sulfides:

- Pyrite $(\mathrm{Fe}, \mathrm{Co}) \mathrm{S}_{2}$

o Pyrrhotite $(\mathrm{Fe}, \mathrm{Co})_{1-x} \mathrm{~S}$
- Sulfarsenides:

o Cobaltite CoAsS

- Glaucodot (Co,Fe)AsS

- Arsenides:

- Safflorite $(\mathrm{Co}, \mathrm{As}) \mathrm{As}_{2}$

o Skutterudite (Co,Fe,Ni)As ${ }_{2-3}$

\section{‡USGS}




\section{Cobalt-Secondary (Supergene) Mineralogy}

- Carbonate minerals:

- Cobaltoan dolomite $(\mathrm{Ca}, \mathrm{Mg}, \mathrm{Co}) \mathrm{CO}_{3}$

- Other minerals:

- Asbolane $(\mathrm{Ni}, \mathrm{Co})_{2-x} \mathrm{Mn}(\mathrm{O}, \mathrm{OH})_{4} \cdot \mathrm{nH}_{2} \mathrm{O}$

- Cobaltiferous oxyhydroxides (geothite, limonite) - it is unclear if the cobalt is within crystal structures or adsorbed onto surfaces

- Erythrite $\mathrm{CO}_{3}\left(\mathrm{AsO}_{4}\right)_{2} \cdot 8 \mathrm{H}_{2} \mathrm{O}$

o Heterogenite $\mathrm{CoO}(\mathrm{OH})$

\section{ఇUSGS}




\section{Cobalt-Occurs in a Wide Variety of Deposit Types}

- Submarine nodules and crusts

- Ni-Co laterites

- Magmatic Ni-Cu sulfide deposits

- Sedimentary rock-hosted deposits

o Stratiform copper deposits

o Mississippi Valley-type (MVT) deposits

- Other carbonate-hosted $\mathrm{Cu}-(\mathrm{Zn}-\mathrm{Pb})$ deposits

- "Synsedimentary and (or) diagenetic" - a spectrum of types

- Co-Cu-Au deposits in metasedimentary rocks

- Iron oxide-copper-gold (IOCG) deposits

- Five-element vein deposits (Ag-Ni-Co-As-Bi) (Kissin, 1992)

- Hydrothermal deposits associated with ultramafic rocks

\section{ॠUSGS}




\section{Cobalt-Submarine Resources}

The largest known cobalt resources are found in submarine Fe-Mn nodules and crusts. Mining them is currently not economic because of legal and technical issues (inability to process the material economically).

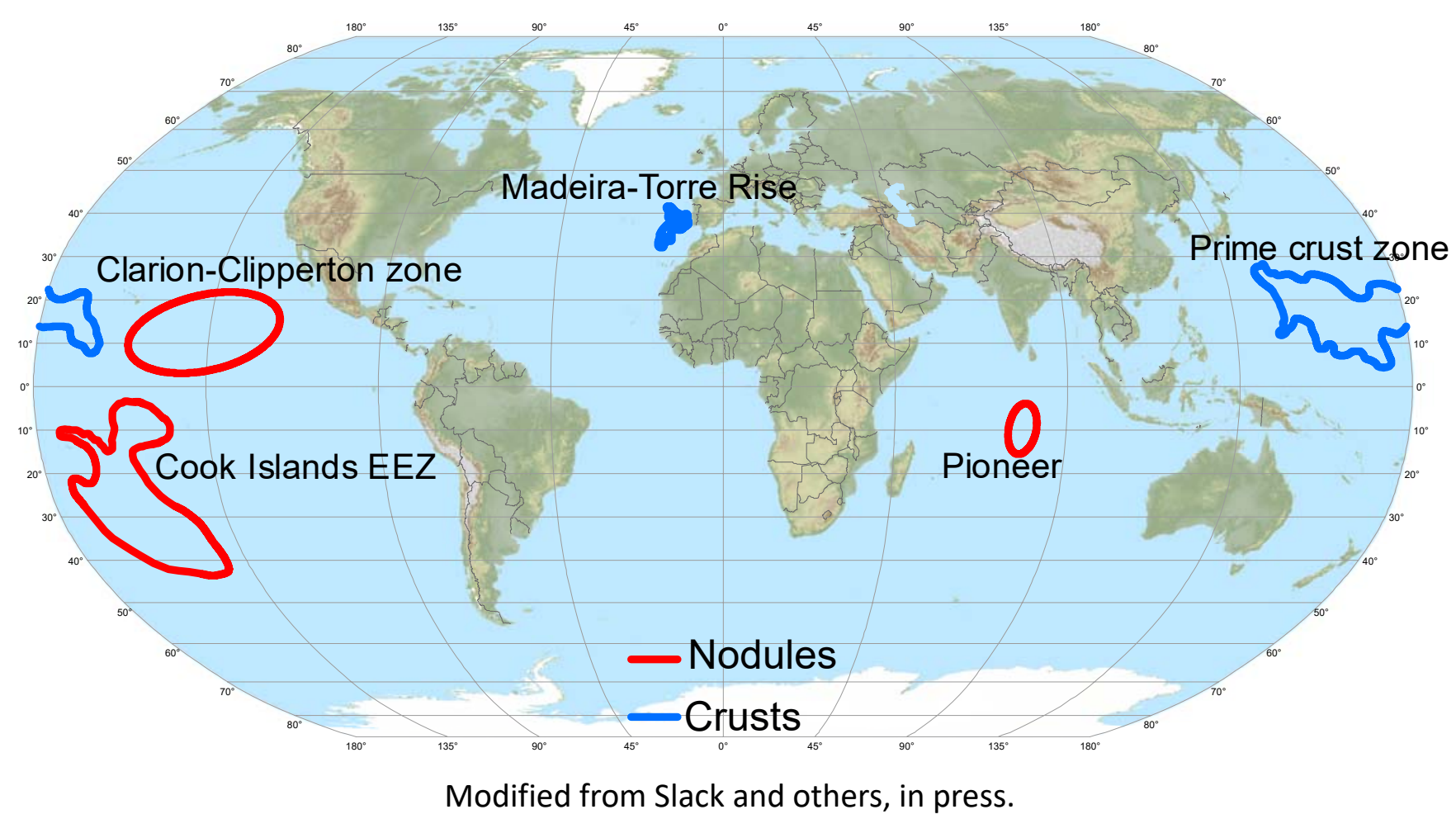

\section{‡USGS}




\section{Cobalt-Deposit Types in Production}

- Laterites (weathered ultramafic rock)

- Australia

o Brazil

- Cuba

- New Caledonia

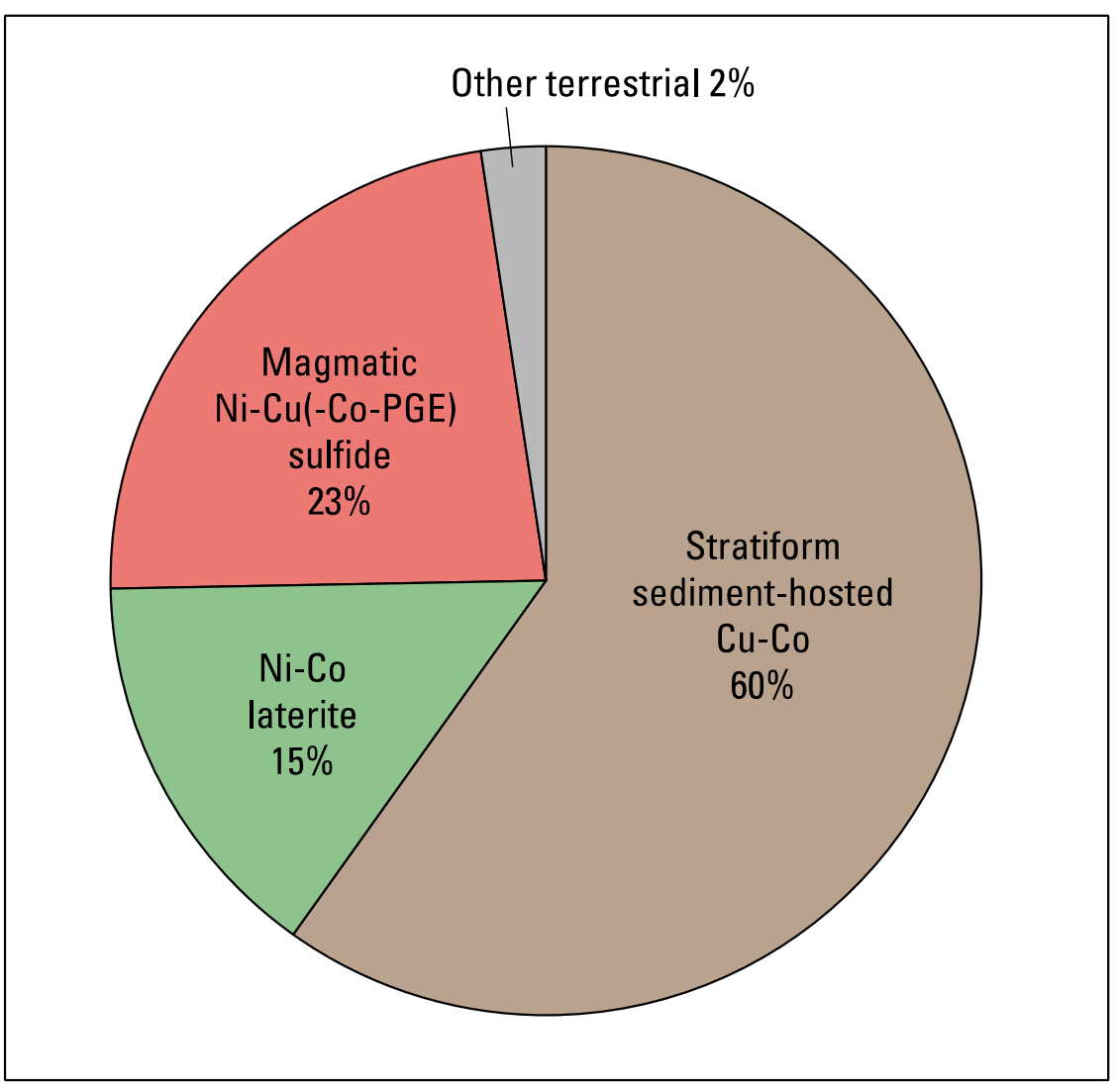

From Slack and others, in press. 


\section{Cobalt-Ni-Co Laterites}

- Consist of-

o Overburden.

o Limonite (higher Co grades).

o Saprolite (higher Ni grades).

o Weathered ultramafic rock.

- Range in thickness from 10 to $40 \mathrm{~m}$.

- Cobalt contained in asbolane, clays (nontronite, montmorillonite), erythrite, goethite, heterogenite, limonite.

- Manganiferous Nkamouna Co-Ni deposit (Cameroon) has cobalt as principal metal recovered.

\section{ఇUSGS}

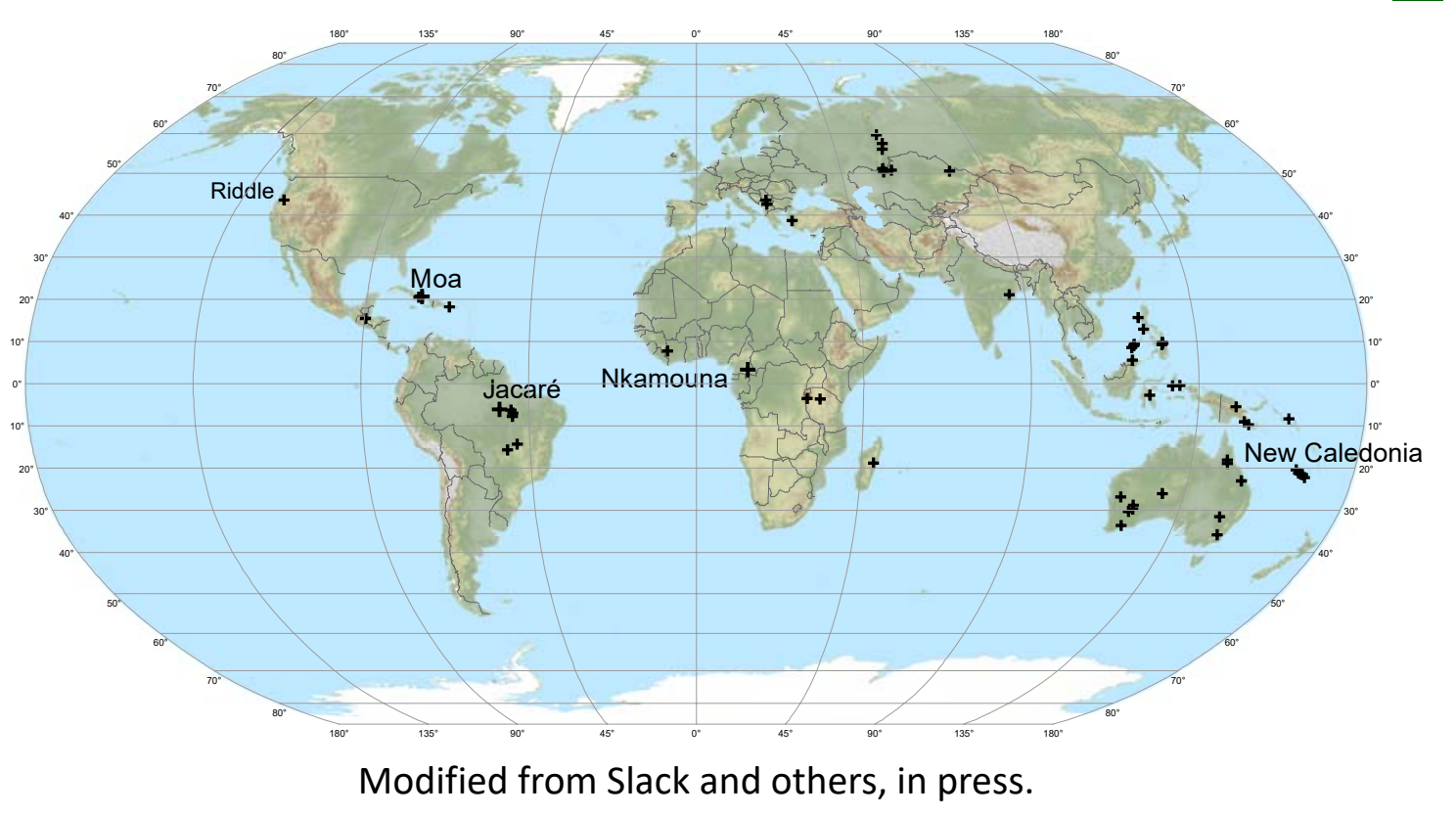

- Mined laterites generally contain $>1 \% \mathrm{Ni}$, cobalt contents:

o Highest: Nkamouna-0.22\% Co.

0 Other higher grade: Moa, Cuba $-0.18 \%$ Co; Jacaré, Brazil-0.13\% Co; New Caledonia- 0.1\% Co.

o Most have $<0.1 \%$ Co; as low as $0.04 \%$ Co. 


\section{Cobalt-Deposit Types in Production}

- Laterites (weathered ultramafic rock)

o Australia

o Brazil

- Cuba

- New Caledonia

- Magmatic Ni-Cu sulfide deposits

o Canada

- China o Cobalt is a byproduct of sulfides

o Russia mined for $\mathrm{Ni}$-Cu-(PGEs) in mafic-ultramafic intrusions.

- Cobalt is correlated with nickel grade; the higher the Ni grade, the higher the amount of Co.

- Cobalt recoveries from magmatic ores are lowgenerally $20 \%$ to $66 \%$.

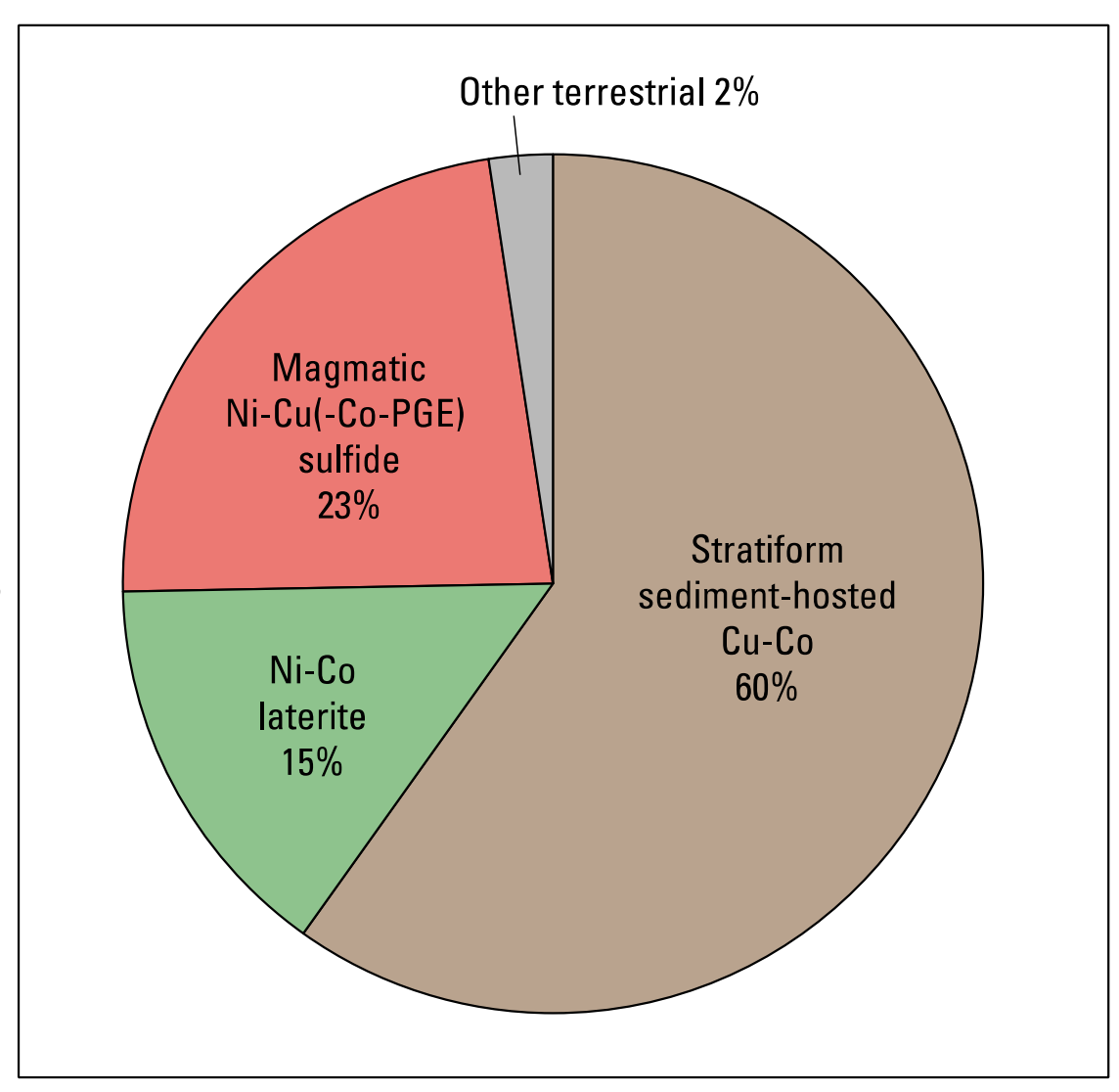

From Slack and others, in press. 


\section{Cobalt-Magmatic Ni-Cu Sulfide Deposits}

- Cobalt is a byproduct of sulfides mined for $\mathrm{Ni}$-CU-(PGEs) in maficultramafic intrusions.

- Sulfides occur in disseminated, nettextured, and massive zones-

0 As basal accumulations in komatiitic flows (Raglan, Kambalda),

differentiated sills (Noril'sk-Talnakh), and layered intrusions (Sudbury, Duluth).

- As stratabound units in layered intrusions (Bushveld, Stillwater).

o In discordant magmatic conduits (Voisey's Bay, Eagle).



- Wide range of cobalt grades:

- Cobalt is found primarily in pentlandite, and in lesser amounts, in linnaeite.

\section{ॠUSGS}

\begin{tabular}{|l|l|l|l|}
\hline Kambalda & $0.21 \%$ & Raglan & $0.06 \%$ \\
\hline Voisey's Bay & $0.09 \%$ & Sudbury & $0.04 \%$ \\
\hline Eagle & $0.08 \%$ & Bushveld & $0.03 \%$ \\
\hline Noril'sk-Talnakh & $0.06 \%$ & Duluth & $0.01 \%$ \\
\hline
\end{tabular}




\section{Cobalt-Deposit Types in Production}

- Laterites (weathered ultramafic rock)
- Australia
- Brazil
- Cuba
- New Caledonia

- Magmatic Ni-Cu sulfide deposits
- Canada
o China
- Russia

- Sedimentary rock-hosted stratiform copper deposits

- Congo (Kinshasa)

- Zambia

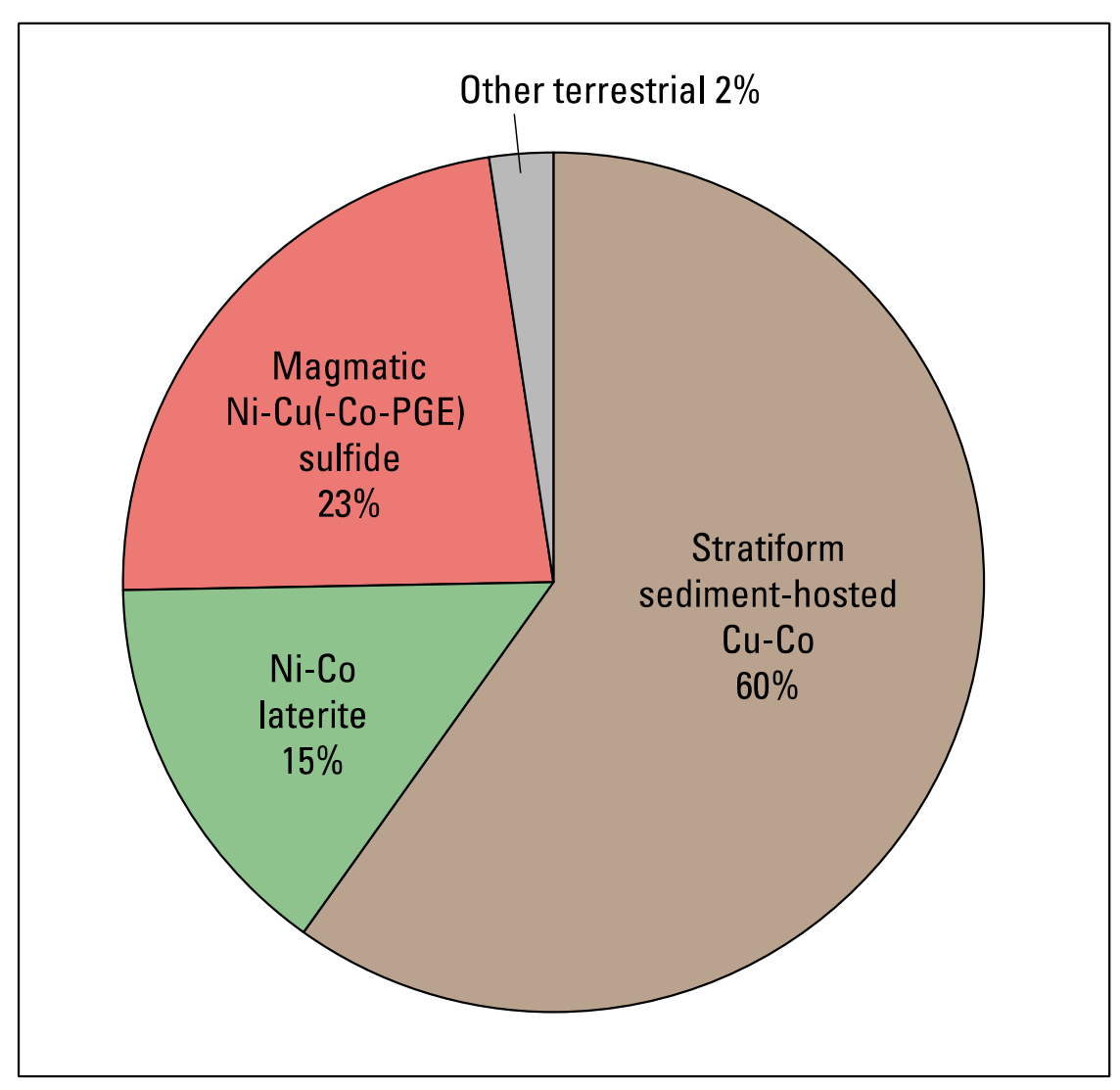

From Slack and others, in press. 


\section{Cobalt-Sedimentary Rock-Hosted Stratiform Copper}

- Only one sedimentary rock-hosted stratiform copper district contains economic cobalt resources-the Central African Copperbelt (CACB).

- In this district, only some deposits have economic (byproduct) cobalt:

o Western portion of the Zambian Copperbelt (ZCB).

o Most of the Congo Copperbelt (CCB), with the exception of the new Kamoa-Kakula deposit.

o Tilwezembe structure (in the CCB) contains the most cobalt-rich deposits; several have grades sufficient for primary cobalt production (Kisanfu).

- Cobalt occurs as carrollite (hypogene).



- Cobalt grades:

\begin{tabular}{|l|l|l|l|}
\hline Kisanfu & $1.1 \%$ & Kolwezi & $0.4 \%$ \\
\hline Mukondo & $0.7 \%$ & Tenke & $0.3 \%$ \\
\hline Tilwezembe & $0.6 \%$ & Luanshya & $0.2 \%$ \\
\hline Nchanga & $0.4 \%$ & Nkana & $0.1 \%$ \\
\hline
\end{tabular}




\section{Spatial Distribution of Central African Copperbelt Copper Deposits}
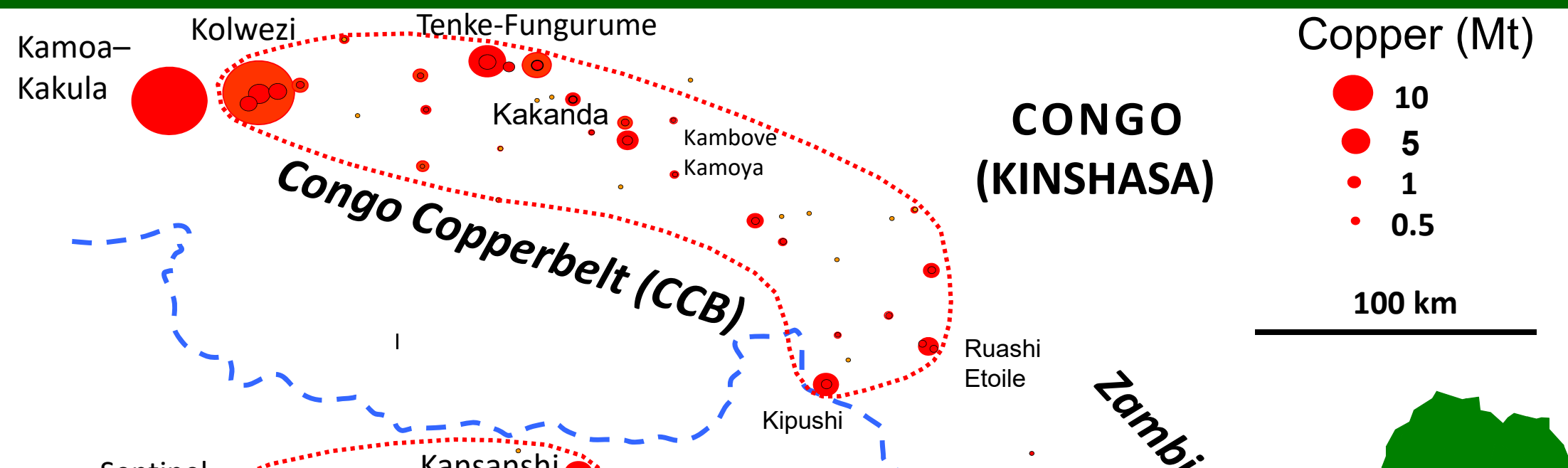

- Deposits occur in distinct linear belts and alignments.

- ZCB and CCB are geographically separate copper provinces.

- ZCB has fewer deposits but contains most of the giants ( $60 \%$ of endowment).

- $\quad$ CCB has many small deposits, but fewer giants ( $40 \%$ of endowment).

\section{ÆUSGS}

\section{ZAMBIA}

\section{Konkolä} Nchanga Chambish

Ruashi

Etoile
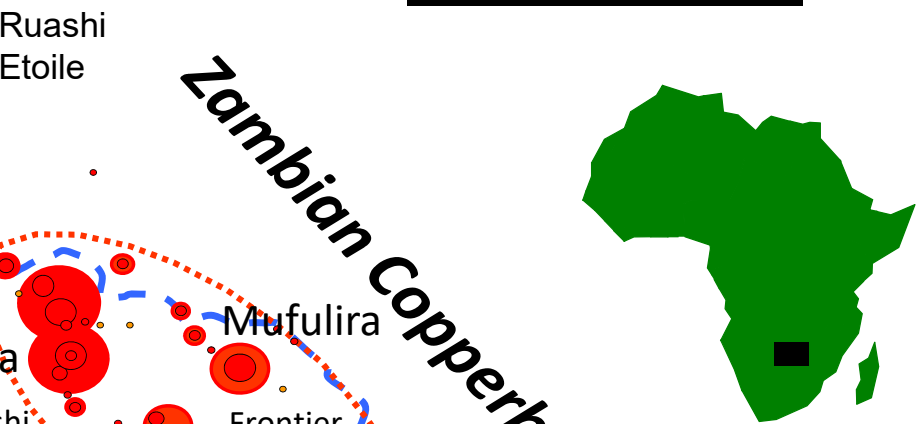

Q. Frontieg":
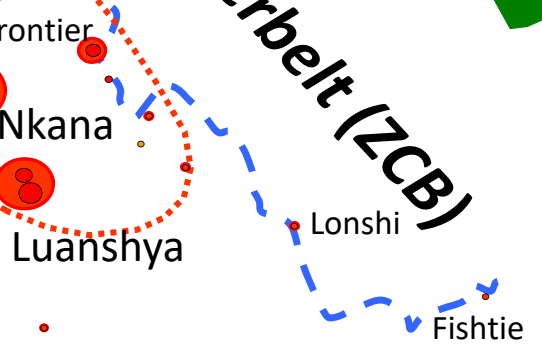


\section{Spatial Distribution of Central African Copperbelt Cobalt Deposits}
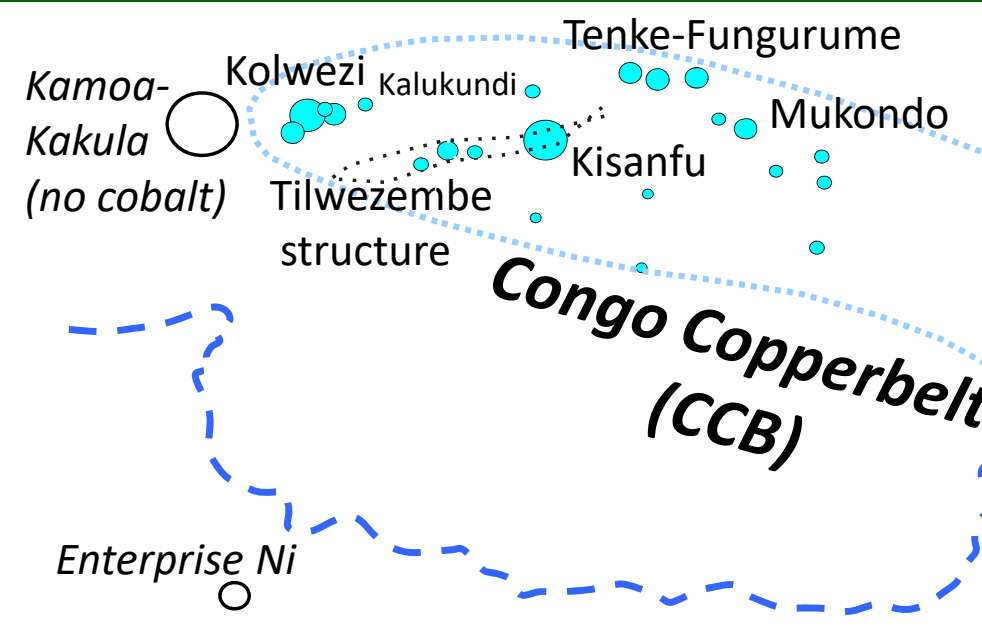

- Cobalt does not always accompany copper.

- Cobalt endowment overwhelmingly favors the CCB, where it is a coproduct in many deposits.

- Cobalt occurrence is restricted to deposits on the western side of the ZCB where it is a byproduct; this area contains abundant mafic intrusions.

\section{ॠUSGS}

Cobalt (Mt)

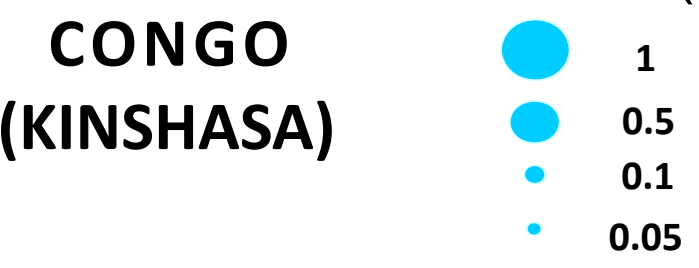

$100 \mathrm{~km}$

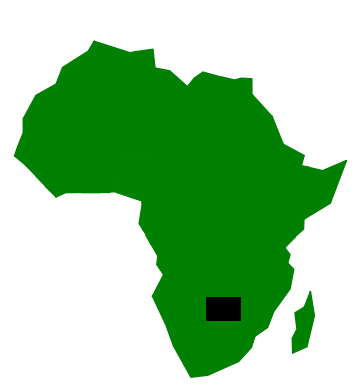

\section{ZAMBIA}




\section{Cobalt-Sedimentary Rock-Hosted Stratiform Copper}

- Although sedimentary rock-hosted stratiform copper deposits currently account for $\sim 60 \%$ of the world's cobalt production, virtually all this output is from one district (CACB).

- An abundance of gabbroic intrusive rocks in the western ZCB and the presence of hydrothermal Ni deposits in the CACB (for example, Enterprise; Capistrant and others, 2015) suggest that mafic rocks may be an important metal source.

- Other sedimentary rock-hosted stratiform copper districts generally contain no or very minor amounts of cobalt (for example, Spar Lake [Montana], Kupferschiefer [central Europe], and Dzhezkazgan [Kazakhstan]).

This type of deposit should not be considered a typical cobalt exploration target.

\section{‡USGS}




\section{Cobalt-Other Deposit Types}

- Sedimentary rock-hosted deposits

- Mississippi Valley-type (MVT) deposits

- Other carbonate-hosted $\mathrm{Cu}-(\mathrm{Zn}-\mathrm{Pb})$ deposits

- "Synsedimentary and (or) Diagenetic" - a spectrum of deposits

- Co-Cu-Au deposits in metasedimentary rocks

- IOCG deposits

- Five-element vein deposits (Ag-Ni-Co-As-Bi)

- Hydrothermal deposits associated with ultramafic rocks 


\section{Cobalt-Mississippi Valley-Type (MVT) Deposits}

- Several southeastern Missouri lead district (Old Lead Belt and Viburnum Trend) deposits have copper-rich zones beneath the lead orebodies that have in the past been mined for copper with byproduct cobalt.

- Cobalt occurs primarily in siegenite.

- Southeastern Missouri is an anomalous MVT district:

- $\mathrm{Pb}>>\mathrm{Zn}$; presence of $\mathrm{Cu}-(\mathrm{Co}, \mathrm{Ni})$.

- Deposits formed close to Precambrian basement.

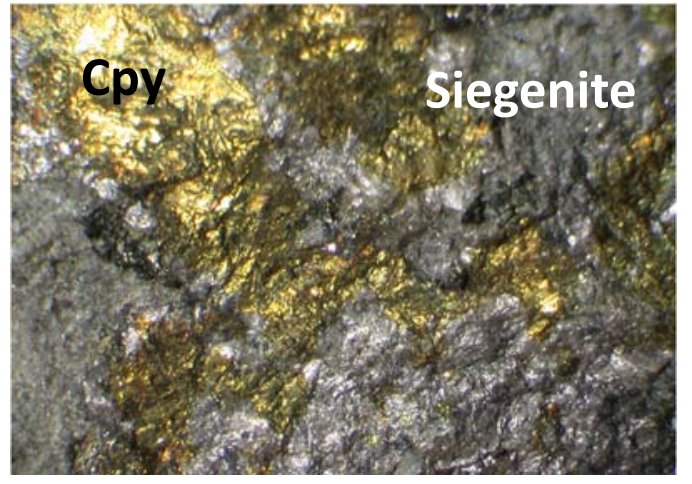

Gray metallic siegenite with brassy chalcopyrite in dull gray limestone. From Fredericktown, Missouri. Field of view is about $1.5 \mathrm{~cm}$ across. Photograph by W. Cordua, Minerals of Wisconsin, http://WGNHS.UWEX.edu/minerals/siegenite. MVT carbonate-hosted Zn-Pb deposits generally do not contain cobalt.

\section{₹USGS}




\section{Cobalt-Other Carbonate-Hosted Cu-(Zn-Pb) Deposits}

- Diverse group of deposits, some of which contain cobalt:

- Ruby Creek (Bornite), Alaska-High-grade portions of the deposit contain up to $0.1 \%$ Co in early cobaltiferous pyrite and later carrollite replacing this pyrite.

- Walford Creek Cu-Zn deposit (Australia) contains cobaltiferous pyrite (Vardy zone; 6.6 Mt at 0.16\% Co; Aeon Metals Ltd., 2017, p. 8).

- Mt. Isa $\mathrm{Cu}$ and $\mathrm{Zn}-\mathrm{Pb}$ orebodies (Australia) contain cobaltiferous pyrite.

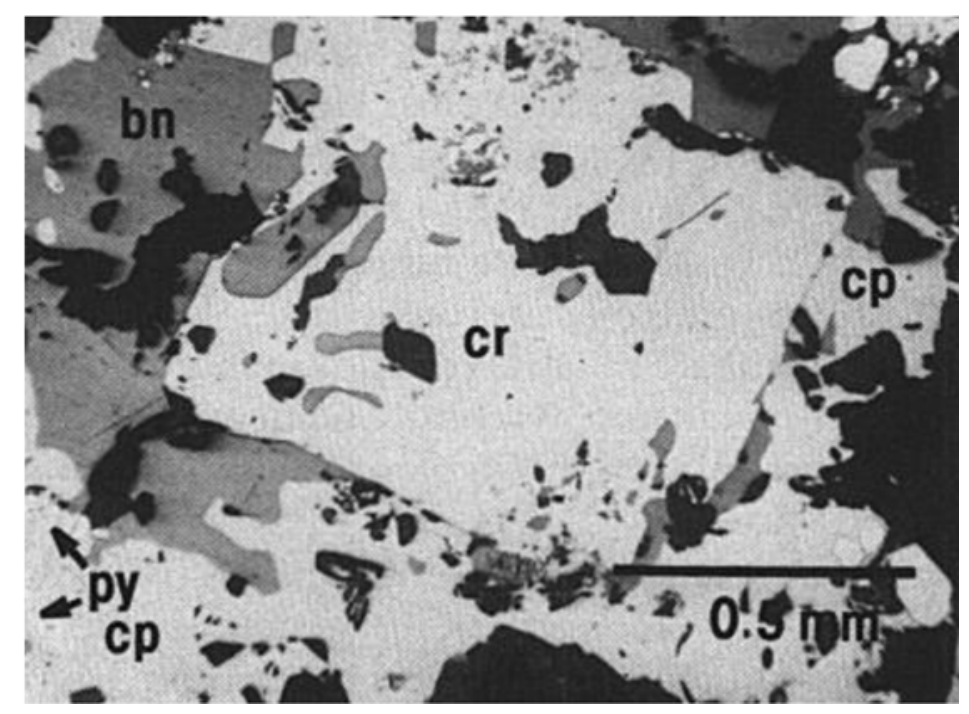

Carrollite intergrown with bornite and chalcopyrite and replacing cobaltiferous pyrite, Ruby Creek deposit, Alaska (Hitzman, 1986, fig. 17). bn, bornite; cp, chalcopyrite; cr, carrollite; py, pyrite

\section{ఇUSGS}




\section{Cobalt— "Synsedimentary and (or) Diagenetic" Deposits}

Spectrum of deposits-Besshi-type volcanogenic massive sulfide (VMS) deposits.

- VMS deposits with enhanced cobalt-often termed "Besshi" after $\mathrm{Cu}-\mathrm{Zn}-(\mathrm{Ag}, \mathrm{Au})$ deposits in Japan - that contain $~ 0.05 \%$ Co in cobaltiferous pyrite, are generally iron sulfide rich, and occur in reduced $\mathrm{C}$-rich (some $\mathrm{Mn}$-rich) sediments with associated maficultramafic rocks in back arc and oceanic rift environments.

o Besshi (Japan)-30 Mt at 0.05\% Co.

o Windy Craggy (Canada)-138 Mt at $0.66 \%$ Co.

o Outokumpu (Finland) $-29 \mathrm{Mt}$ at $0.25 \%$ Co.

o Ducktown (Tennessee)-163 Mt, Co grade is unknown.

\section{ॠUSGS}

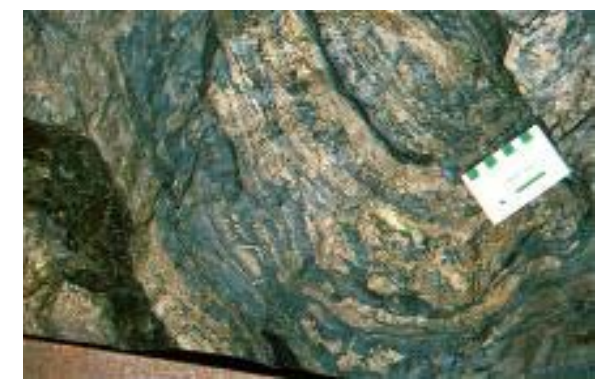

Pyritic massive sulfide from the Windy Craggy deposit. Image courtesy of Jan Peter. 


\section{Cobalt— "Synsedimentary and (or) Diagenetic" Deposits}

Spectrum of deposits-Black shale deposits.

- In black (C-rich) shales deposited in a rift basin with ultramafic rocks (now talc-carbonate).

- Shales may contain manganese as alabandite (MnS).

- Cobalt occurs primarily in cobaltiferous pyrite.

- Primary example is the Talvivaara deposit (Finland) $-1,550 \mathrm{Mt}$ at $0.02 \% \mathrm{Co}, 0.22 \% \mathrm{Ni}, 0.13 \% \mathrm{Cu}$, and $0.49 \% \mathrm{Zn}$. 


\section{Cobalt-Other Sediment-Hosted Deposits}

\section{Spectrum of deposits-Shale-hosted deposits.}

- Sullivan deposit (Canada) contained cobalt in arsenopyrite (not recovered).

- Sheep Creek (Black Butte), Montana, contains 9.1 Mt at $0.12 \%$ Co in cobaltiferous pyrite (minor amount of siegenite).

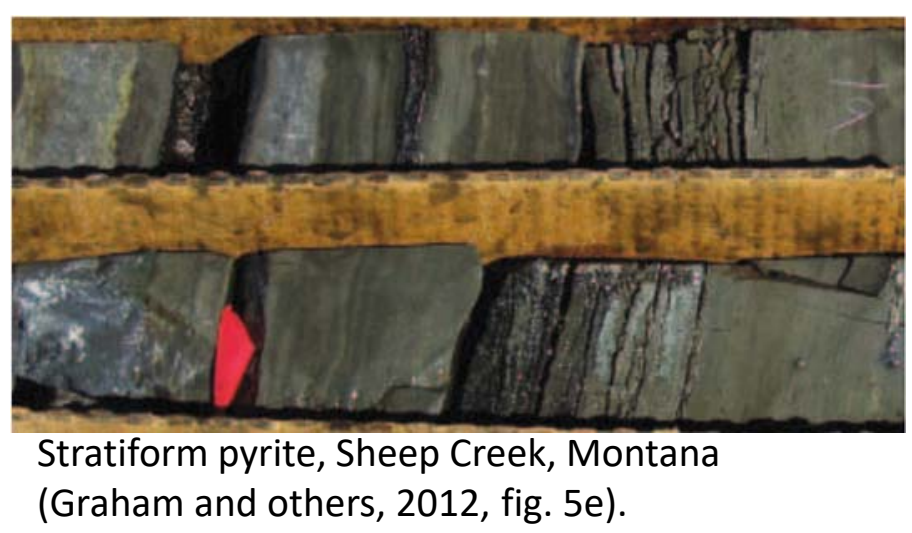

(Graham and others, 2012, fig. 5e).

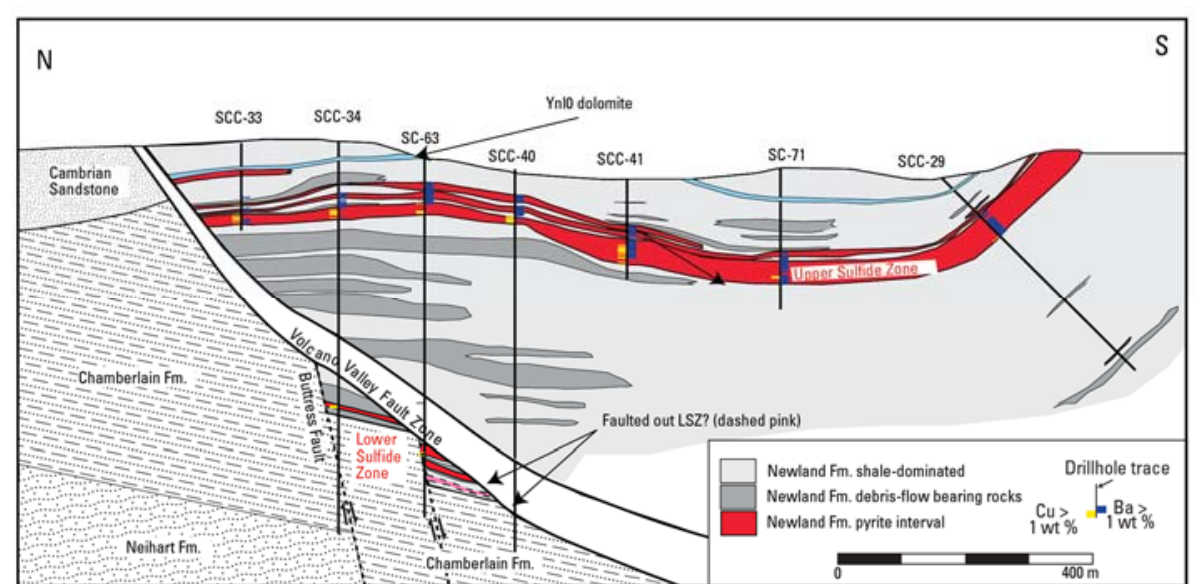

Cross section, Sheep Creek, Montana (Graham and others, 2012, fig. 7). 


\section{Cobalt— "Synsedimentary and (or) Diagenetic" Deposits}

\section{Spectrum of deposits-Mn-rich deposits.}

- Atlantis II Zn-Cu-(Ag, Co) (Red Sea)

o Mudstones and chemical sediments in small basins in oceanic rift with evaporites above mafic volcanic and intrusive rocks.

o Upper Mn-rich zone and lower Fe-rich zone ( 89 Mt). Mn and Fe as oxyhydroxides with $0.05 \%$ Co.

- Boleo Cu-Zn-(Co) (Mexico)

- Mudstones interbedded with siltstones and conglomerates deposited adjacent to evaporites and above basalts in proto-Gulf of California rift.

- Stacked mantos of sulfide and Fe- and Mn-oxide-rich material (sulfide$264 \mathrm{Mt}$ of $0.06 \%$ Co-in oxyhydroxides and cobaltiferous pyrite).

\section{‡USGS}




\section{Spectrum of Co-bearing "Synsedimentary and (or) Diagenetic" Deposits}

- These deposits formed on or near the sea floor surface by exhalation and infiltration of hydrothermal fluids (heated seawater) that reacted with sediments and mafic-ultramafic rocks to derive Fe-Cu-Zn-Co-Ni.

- These are fundamentally iron sulfide (and in some cases iron and manganese oxide) deposits with relatively minor amounts of trace metals.

- The presence of manganese is probably controlled by water depth and the oxidation state of both the hydrothermal fluids and the ocean water.

- The tectonic environments vary from incipient rifts with oceanic crust to back arc basins. The presence of evaporites in the section probably helps to increase hydrothermal fluid salinity and the ability of the fluids to carry additional cobalt.

\section{ఇUSGS}




\section{Cobalt-Co-Cu-Au in Metasedimentary Rocks}

- Stratabound to discordant zones of semimassive to locally massive sulfides within deformed siliciclastic metasedimentary rocks.

- Contain cobaltite with lesser amounts of (and later formed) chalcopyrite, pyrite, pyrrhotite, and cobaltiferous arsenopyrite.

- Primary example is the Blackbird district (Idaho) for which historical production plus current reserves total $17 \mathrm{Mt}$ at $0.7 \% \mathrm{Co}, 1.4 \% \mathrm{Cu}$, and $1 \mathrm{ppm} \mathrm{Au}$ (individual deposits are open at depth).

Cross section, Blackbird district: Sulfides are predominantly stratabound within metamorphosed Mesoproterozoic biotite-rich banded siltites of the Apple Creek Formation.

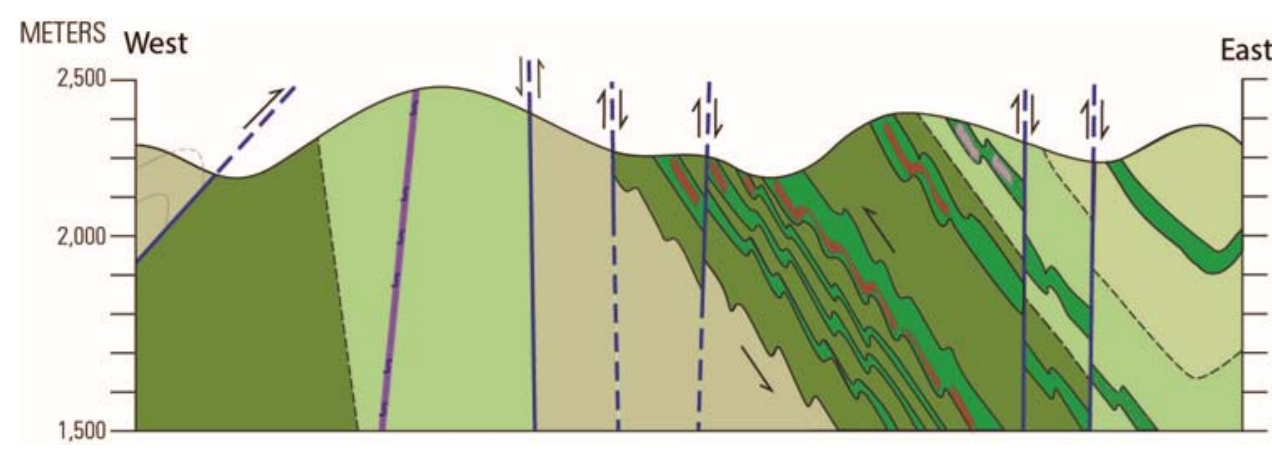




\section{Cobalt—Blackbird District, Idaho}

- Host sediments are older than 1,410 Ma.

- Absence of significant mafic rocks in the area.

- The mineralized banded siltite unit was also pervasively

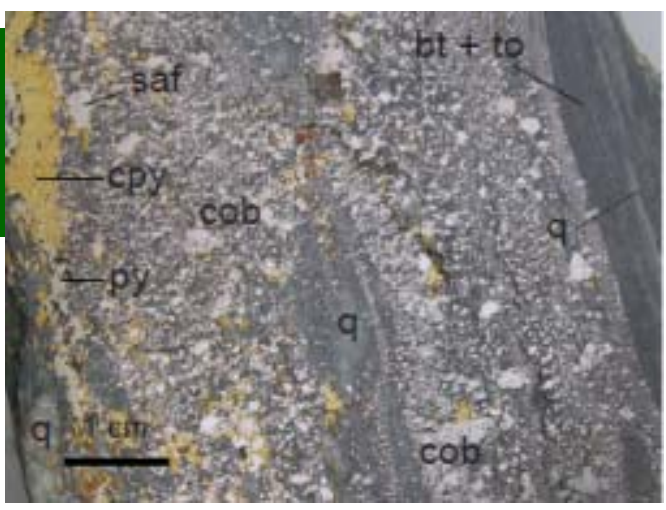

Photograph by Art Bookstrom. biotitized $\left(\mathrm{Fe}^{2+}, \mathrm{Cl}-\mathrm{rich}\right)$.

- The cobaltite-biotite-(tourmaline-xenotime-Au) ore (dominant) is younger than the xenotime dated 1,370 Ma but older than the xenotime dated 1,316 to $1,270 \mathrm{Ma}$ (Aleinikoff and others, 2012); the Re-Os age is 1,349 $\pm 76 \mathrm{Ma}$ (Saintilan and others, 2017). Time period includes an orogenic event.

- The mineralizing fluids were probably reduced and highly saline.

- There was an overprinting Cretaceous-age quartz-chalcopyrite-pyritecobaltiferous arsenopyrite-(Au) event.

\section{ఇUSGS}




\section{Cobalt-Iron Oxide-Copper-Gold (IOCG) Deposits}

- IOCG deposits are a still poorly understood class of deposits apparently formed by crustal-scale hydrothermal systems that consist of significant iron oxides (magnetite and [or] hematite) with chalcopyrite and gold. They commonly contain a variety of trace metals, including $\mathrm{U}, \mathrm{Ag}, \mathrm{Co}, \mathrm{Ni}, \mathrm{Bi}$, and often have extensive zones of potassic alteration enclosing the ore.

- Currently, no IOCGs are producing byproduct cobalt, although a number contain significant resources. The NICO deposit in Canada (Cu-poor IOCG variant) is slated to come into production as a primary cobalt producer.

\begin{tabular}{|l|l|}
\hline Olympic Dam (Australia) & $650 \mathrm{Mt}$ at $0.02 \%$ \\
\hline Ernest Henry (Australia) & $166 \mathrm{Mt}$ at $0.05 \%$ \\
\hline Boss Bixby (Missouri) & $40 \mathrm{Mt}$ at $0.04 \%$ \\
\hline NICO (Canada) & $31 \mathrm{Mt}$ at $0.12 \%$ \\
\hline Guelb Moghrein (Mauritania) & $24 \mathrm{Mt}$ at $0.14 \%$ \\
\hline
\end{tabular}

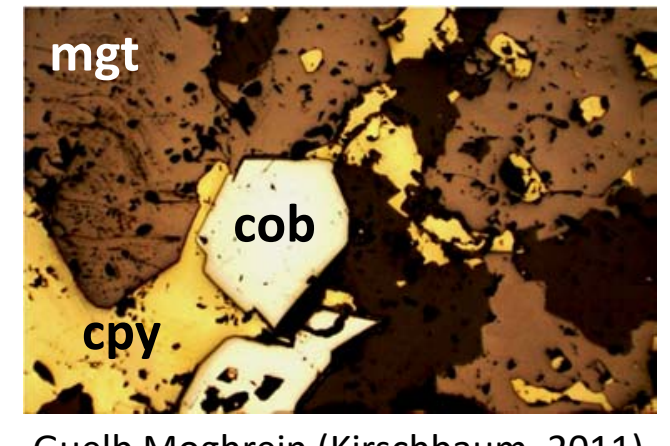




\section{Cobalt-Five-Element Vein Deposits}

- $\mathrm{Ag}-\mathrm{Ni}-\mathrm{Co}-\mathrm{As}-\mathrm{Bi}-(\mathrm{U}-\mathrm{REE})$ veins have been recognized as a distinctive ore type since the early 20th century (Bastin, 1939) and were the historic silver mines of Europe (Erzebirge [Czechoslovakia, Germany]; Schwarzwald [Germany]; Kongsberg [Norway]). In Canada, major districts are Cobalt-Gowganda, Thunder Bay, and Echo Bay. In the United States, similar deposits were mined at Wickenberg (Arizona) and Black Hawk (Silver City, New Mexico). All these deposits produced silver, some produced uranium, and a few produced cobalt.

- Grades and tonnage at many deposits are hard to determine owing to old records.

- Keeley-Frontier Mine (Cobalt district) produced nearly 1,500 Mt at grades of $0.5 \%$ Co and 1,644 g/t Ag (The Northern Miner, 2017).

\section{ॠUSGS}




\section{Cobalt-Five-Element Vein Deposits (Continued)}

- These deposits generally occur in crystalline terranes (metamorphic or granitic rocks) and do not appear to be genetically associated with magmatic rocks (mafic or felsic).

- The deposits typically consist of open-space-filling veins up to several meters in width that pinch and swell.

- Maximum depths to which veins have been mined is approximately $500 \mathrm{~m}$ and, in some districts, the veins are barren at depth.

- There is virtually no wallrock alteration around the veins. Where wallrock alteration is present, it is weak chloritization.

\section{ఇUSGS}




\section{Five-Element Vein Deposits—Sequential Mineralogical Stages}

(1) Early quartz with minor amounts of pyrite, sphalerite, galena.

(2) Uraninite-quartz.

(3) Native silver with $\mathrm{Ni}-\mathrm{Co}$ arsenide minerals and sometimes native bismuth with calcite or dolomite.

(4) Pyrite, sphalerite, galena, chalcopyrite with native silver and argentite and calcite, and minor amounts of quartz, fluorite, and barite.

(5) Late-stage calcite, sometimes with barite or fluorite. 


\section{Cobalt-Five-Element Vein Deposits}

- Several fluid inclusion studies indicate progression to the highest temperature $\left(300\right.$ to $500^{\circ} \mathrm{C}$ ) during the $\mathrm{Ag}-\mathrm{Ni}$-Co stage, down to $150^{\circ} \mathrm{C}$ during the sulfide stage, and to below $125^{\circ} \mathrm{C}$ for late-stage calcite.

- Evidence of multiple pulses of fluids, multiple T maxima. Hightemperature-stage fluids ( $\mathrm{Ag}, \mathrm{Co}, \mathrm{Ni}, \mathrm{As}$ ) were $\mathrm{NaCl}$ saturated.

- Evidence of boiling in some districts, and trapping pressures at Cobalt, Ontario, suggest ore deposition at $700 \mathrm{~m}$ (Kerrich and others, 1986).

\section{ॠUSGS}




\section{Cobalt-Metased Co-Cu-Au-IOCG-Five-Element Vein}

- These deposit types, though distinct, have some similarities:

- Metal suite ( $\mathrm{Co}, \mathrm{Ni}, \mathrm{Ag}, \mathrm{Au})$ with differences regarding amount of $\mathrm{Fe}, \mathrm{Cu}, \mathrm{As}, \mathrm{U}$, and $\mathrm{Bi}$.

o Formed by hydrothermal fluids that do not appear to be directly related to igneous activity.

o Fluids with high salinity and low reduced sulfur content (generally low iron sulfides) at temperatures of $\sim 500$ to $250{ }^{\circ} \mathrm{C}$.

Causative fluids formed by deep crustal heating?

\section{ఇUSGS}




\section{Candelaria District, Chile-A Model to Tie Together IOCG, Metased $\mathrm{Co}-\mathrm{Cu}-\mathrm{Au}$, and Five-Element Vein Deposits?}

- IOCG system with deep magnetite zone and hematite zone above the magnetite zone.

- Massive biotititeanalogy to Blackbird?

- System is capped by calcite veins containing $\mathrm{Ag}$ and intrusive W siltstone

Calcite

skam $(+\mathrm{Ag}, \mathrm{Co})$

limestone

homfels

Potassic alteration (biotite)

Sodic-calcic alteration

\section{hm-c py-Au}

andesite

Co (five-element veins). 


\section{Cobalt-Hydrothermal Deposits Associated with Ultramafic Rocks (Bou Azzer District, Morocco)}

- The Bou Azzer district of Morocco is a primary producer of cobalt (with byproduct nickel and gold).

- More than 60 individual deposits are known.

- District contains approximately $6 \mathrm{Mt}$ at $1 \% \mathrm{Co}, 1 \% \mathrm{Ni}$, and $3 \mathrm{~g} / \mathrm{t} \mathrm{Au}$.

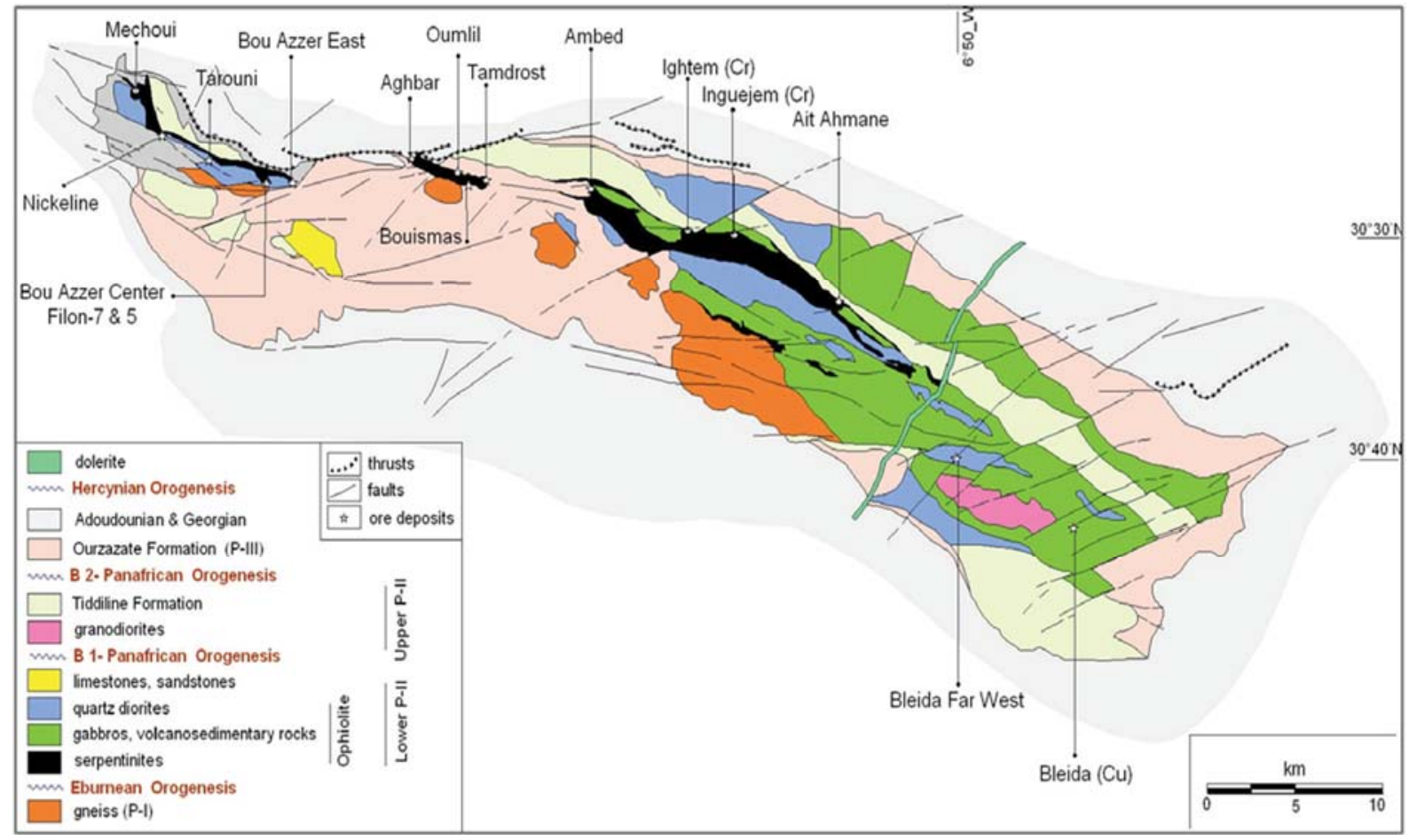

From Oberthür and others, 2009, fig. 1. 
Cobalt-Hydrothermal Deposits Associated with Ultramafic Rocks

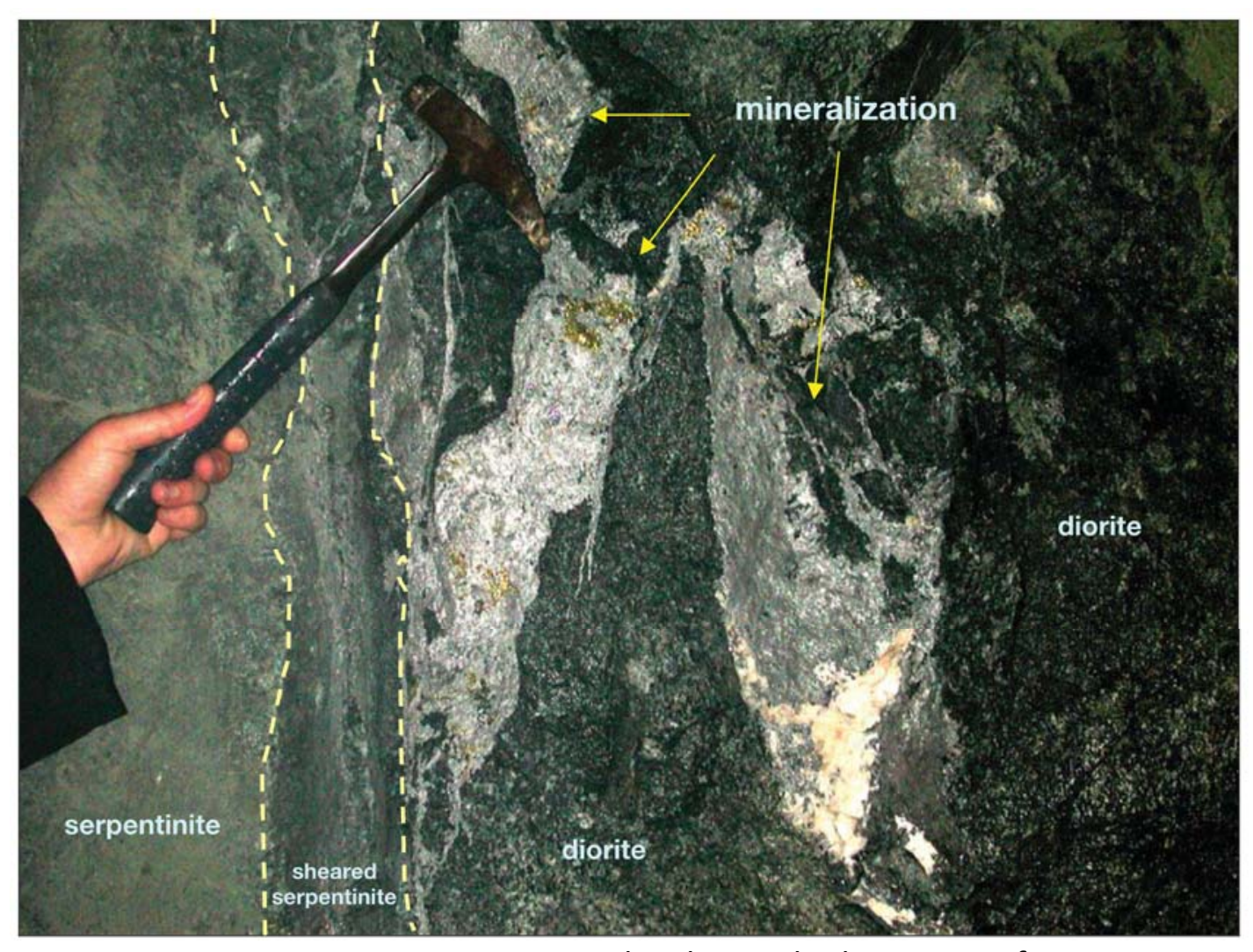

ఇUSGS
- Deposits occur as quartz-calcite veins immediately adjacent to Neoproterozoic serpentinites that are part of an ophiolite along a Pan-African suture zone.

- Mineralization occurred during the Hercynian orogeny ( 310 Ma; Oberthür and others, 2009). 


\section{Cobalt-Bou Azzer Cobalt Deposit}

- There is a sequential increase in $\mathrm{Co}$ and As precipitation through time from $\mathrm{Ni}$ monoarsenides (nickeline) to $\mathrm{Ni}$-Co diarsenides (rammelsburgite) to cobalt triarsenides (skutterudite) to sulfarsenides (arsenopyrite) to copper sulfides. Quartz and carbonate minerals fill spaces and fractures between ore minerals.

- The mineralogical paragenetic sequence is probably the result of decreasing temperatures, increasing $\mathrm{pH}$, and decreasing oxygen fugacity-possibly owing to mixing of hydrothermal and meteoric fluids.

- $\mathrm{Co}, \mathrm{Ni}, \mathrm{Fe}, \mathrm{Cu}$ and $\mathrm{As}$ were probably leached from the serpentinites by relatively low $\mathrm{pH}$, saline fluids.

- The predominance of Co over $\mathrm{Ni}$ arsenide minerals despite the high $\mathrm{Ni}-\mathrm{Co}$ ratio in the serpentinites is probably owing to the difference in the solubility of the elements in the hydrothermal fluid (Ahmed and others, 2009).

\section{ఇUSGS}




\section{Cobalt-Summary and Speculation}

- Many cobalt deposits are associated with mafic-ultramafic rocks. The association can be:

o Close-Ni-Co laterites, magmatic Ni-Cu sulfide deposits, hydrothermal deposits associated with ultramafic rocks.

o Intermediate-Besshi-type VMS deposits, black shale deposits.

o Distant-Central African Copperbelt, southeastern Missouri.

- The association is least evident in the metasedimentary Co-Cu-Au, IOCG, and five-element vein deposits.

\section{ॠUSGS}




\section{Cobalt-Summary and Speculation (Continued)}

- The CACB is probably cobaltrich owing to mafic-ultramafic rocks in the underlying basement.

- Most deposits in the BeltPurcell basin also contain at least minor amounts of cobalt, suggesting that it may be similar to the CACB.

- Other styles of sedimentary rock-hosted cobalt deposits may be present in this basin.

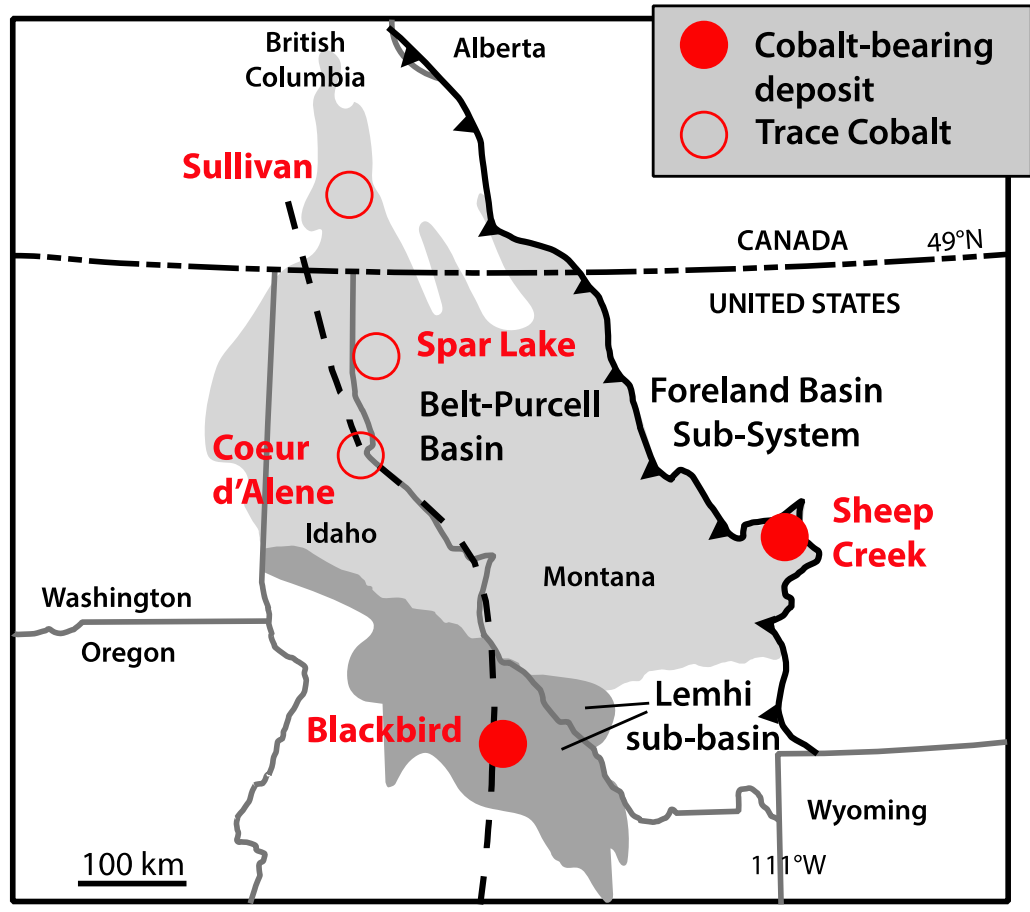

Modified from Bookstrom and others, 2016.

\section{‡USGS}




\section{Cobalt-Summary and Speculation (Continued)}

- Primary Co deposits are restricted to hydrothermal deposits associated with ultramafic rocks and possibly some five-element vein deposits.

- Both deposit types-

o Have relatively poorly defined exploration models.

o Are small targets with weak alteration halos.

o Probably represent primarily Ni-As-Co-Ag geochemical anomalies (elements that have not been routinely analyzed for in the past).

o Are not significant geophysical targets.

o Represent targets for which little exploration has yet been done.

\section{ॠUSGS}




\section{Cobalt-U.S. Exploration}

- Magmatic Ni-Cu in the Archean and Proterozoic rocks of the Midwest and the east coast (Pennsylvania) and younger mafic rocks in southeastern and southern Alaska. Also basement rocks in southeastern Missouri?

- Belt-Purcell basin for different styles of sedimentary rock-hosted cobalt deposits.

- Besshi-type VMS deposits-Is cobalt present in any of the ore lenses at the Greens Creek (Alaska) deposit? Cobalt resource present in Ducktown (Tennessee) waste and tailings?

- Known five-element vein districts in Arizona and New Mexico and potential for additional districts in crystalline rocks in and adjacent to the Basin and Range Province. Additionally, in the Yukon-Tanana terrane of Alaska, which has geologic similarities to European Hercynian terranes.

- Hydrothermal deposits associated with ultramafic rocks along the west coast, in Alaska, and in the Appalachian Mountains.

\section{ॠUSGS}




\section{References Cited -1}

Aeon Metals Ltd., 2017, Walford Creek Project development: Aeon Metals Ltd., May, Presentation, 21 p. plus 6 appendixes, accessed November 9, 2017, at http://aeonmetals.com.au/assets/uploads/ 2017/05/Company-Presentation-May-2017.pdf.

Ahmed, H.A., Arai, Shoji, and Ikenne, Moha, 2009, Mineralogy and paragenesis of the Co-Ni arsenide ores of Bou Azzer, Anti-Atlas, Morocco: Economic Geology, v. 104, p. 249-266. (Also available at https://doi.org/10.2113/gsecongeo.104.2.249.)

Aleinikoff, J.N., Slack, J.F., Lund, Karen, Evans, K.V., Fanning, C.M., Mazdab, F.K., Wooden, J.L., and Pillers, R.M., 2012, Constraints on the timing of $\mathrm{Co}-\mathrm{Cu}+\mathrm{Au}$ mineralization in the Blackbird district, Idaho, using SHRIMP U-Pb ages of monazite and xenotime plus zircon ages of related Mesoproterozoic orthogneisses and metasedimentary rocks: Economic Geology, v. 107, p. 1143-1175. (Also available at https://doi.org/10.2113/econgeo.107.6.1143.)

Bastin, E.S., 1939, The nickel-cobalt-native silver ore type: Economic Geology, v. 34, p. 1-40. (Also available at https://doi.org/10.2113/gsecongeo.34.1.1.)

Bookstrom, Art, Box, Steve, Cossette, Pam, Frost, Tom, Gillerman, Virginia, King, George, and Zirakparvar, Alex, 2014, Structure, tectonics, and metamorphism of the Blackbird Co-Cu deposit and its metasedimentary host rocks, Rocky Mountain (66th Annual) and Cordilleran (110th Annual) Joint Meeting, May 19-21, 2014, Presentation, in Geological Society of America Abstracts with Programs, v. 46, no. 5, p. 96. (Also available at https://gsa.confex.com/gsa/2014RM/webprogram/Paper238668.html.)

\section{ॠUSGS}




\section{References Cited -2}

Bookstrom, A.A., Box, S.E., Cossette, P.M., Frost, T.P., Gillerman, V.S., King, G.R., and Zirakparvar, N.A., 2016, Geologic history of the Blackbird Co-Cu district in the Lemhi subbasin of the Belt-Purcell basin, in MacLean, J.S., and Sears, J.W., eds., Belt basin-Window to Mesoproterozoic Earth: Geological Society of America Special Paper 522, p. 1-35. (Also available at https://pubs.er.usgs.gov/publication/70188880.)

Capistrant, P.L., Hitzman, M.W., Wood, David, Kelly, N.M., Williams, Gretchen, Zimba, Munshya, Kuiper, Yvette, Jack, Doug, and Stein, Holly, 2015, Geology of the Enterprise hydrothermal nickel deposit, North-Western Province, Zambia: Economic Geology, v. 110, p. 9-38. (Also available at https://doi.org/10.2113/econgeo.110.1.9.)

Graham, Garth, Hitzman, M.W., and Zieg, Jerry, 2012, Geologic setting, sedimentary architecture, and paragenesis of the Mesoproterozoic sediment-hosted Sheep Creek Cu-Co-Ag deposit, Helena Embayment, Montana: Economic Geology, v. 107, p. 1115-1141. (Also available at https://doi.org/10.2113/econgeo.107.6.1115.)

Hitzman, M.W., 1986, Geology of the Ruby Creek copper deposit, southwestern Brooks Range, Alaska: Economic Geology, v. 81, p. 1644-1674. (Also available at https://doi.org/10.2113/gsecongeo.81.7.1644.)

\section{ॠUSGS}




\section{References Cited -3}

Kerrich, R., Strong, D.F., Andrews, A.J., and Owsiacki, L., 1986, The silver deposits at Cobalt and Gowganda, Ontario III: Hydrothermal regimes and source reservoirs-Evidence from $\mathrm{H}, \mathrm{O}, \mathrm{C}$, and $\mathrm{Sr}$ isotopes and fluid inclusions: Canadian Journal of Earth Sciences, v. 23, no. 10, p. 1519-1550. (Also available at https://doi.org/10.1139/e86-145.)

Kirschbaum, M.J., 2011, Geology of the Guelb Moghrein iron oxide copper-gold deposit: Unpublished M.S. thesis, Golden, CO, Colorado School of Mines, 88 p.

Kissin, S.A., 1992, Five-element (Ni-Co-As-Ag-Bi) veins: Geoscience Canada, v. 19, no. 3, p. 113-124. (Also available at https://journals.lib.unb.ca/index.php/GC/article/view/3768/4282.)

McCullough, Erin, and Nassar, N.T., 2017, Assessment of critical minerals-Updated application of an early-warning screening methodology: Mineral Economics, September 19, p. 1-16. (Also available at https://doi.org/10.1007/s13563-017-0119-6.)

Oberthür, Thomas, Melcher, Frank, Henjes-Kunst, Friedhelm, Gerdes, Axel, Stein, Holly, Zimmerman, Aaron, and El Ghorfi, Mustapha, 2009, Hercynian age of the cobalt-nickel-arsenide-(gold) ores, Bou Azzer, Anti-Atlas, Morocco-Re-Os, Sm-Nd, and U-Pb age determinations: Economic Geology, v. 104, p. 1065-1079. (Also available at https://doi.org/10.2113/econgeo.104.7.1065.)

\section{‡USGS}




\section{References Cited -4}

Saintilan, N.J., Creaser, R.A., and Bookstrom, A.A., 2017, Re-Os systematics and geochemistry of cobaltite (CoAsS) in the Idaho cobalt belt, Belt-Purcell basin, USA-Evidence for middle Mesoproterozoic sediment-hosted Co-Cu sulfide mineralization with Grenvillian and Cretaceous remobilization: Ore Geology Reviews, v. 86, p. 509-525. (Also available at http://dx.doi.org/10.1016/j.oregeorev.2017.02.032.)

Slack, J.F., Kimball, B.E., and Shedd, K.B., [in press], Cobalt, chap. F of Schulz, K.J., DeYoung, J.H., Jr., Seal, R.R., II, and Bradley, D.C., eds., Critical mineral resources of the United States-Economic and environmental geology and prospects for future supply: U.S. Geological Survey Professional Paper 1802, p. F1-F39.

The Northern Miner, 2017, First Cobalt acquires assets in Canada and the DRC: The Northern Miner, May 5, accessed November 9, 2017, at https://firstcobalt.com/2017/northern-miner-first-cobaltacquires-assets-canada-drc/.

U.S. Geological Survey, 2017, Mineral commodity summaries 2017: U.S. Geological Survey, 202 p. (Also available at https://doi.org/10.3133/70180197.)

\section{‡USGS}

